\title{
Immunopathology of fatal soybean dust-induced asthma
}

\author{
M. Synek*, J.M. Antó*, R. Beasley**, A.J. Frew*, L. Holloway*, F.C. Lampe*, \\ J.L. Lloreta+, J. Sunyer+, A. Thornton*, S.T. Holgate*
}

Immunopathology of fatal soybean dust-induced asthma. M. Synek, J.M. Antó, R. Beasley, A.J. Frew, L. Holloway, F.C. Lampe, J.L. Lloreta, J. Sunyer, A. Thornton, S.T. Holgate. (C)ERS Journals Ltd 1996.

ABSTRACT: A hypothesis was postulated that the characteristic clinical course of fatal soybean asthma may be reflected by specific immunopathological findings.

Seven cases of fatal soybean dust-induced asthma from Barcelona, Spain were compared with 25 fatal asthma cases from New Zealand. Sections of lung tissue were stained by monoclonal antibodies using standard streptavidin-biotin peroxidase technique. The following cell types were identified: mast cells, "activated" eosinophils, neutrophils, monocytes/macrophages, CD3+ T-cells and CD8+ T-cells. The positively staining cells were counted in the epithelium and the submucosa and their numbers expressed per $\mathbf{m m}$ and $\mathbf{~ m m}^{2}$, respectively. The airways were divided into larger (internal perimeter $(\mathbf{P i})>2 \mathrm{~mm}$ ) and smaller $(\mathbf{P i}<2 \mathrm{~mm})$. Firstly, all airways were studied together; and subsequently, larger and smaller airways were studied separately.

Differences in the numbers of mast cells, eosinophils, neutrophils and monocytes/macrophages between the two groups were not significant. The numbers of CD3+ and CD8+ T-cells were significantly reduced in fatal soybean asthma when all airways were taken together. In larger airways, the difference was not significant in the epithelium, but was significant in the submucosa for CD3+ cells. CD8+ cells were significantly reduced in fatal soybean asthma both in the epithelium and the submucosa. The cell counts in smaller airways were not significantly different either in the epithelium or in the submucosa for CD3+ cells. The numbers of CD8+ cells were not different in the epithelium, but were significantly reduced in the submucosa of fatal soybean asthma cases.

We conclude that the numbers of $\mathrm{CD3}+$ and CD8+ T-cells are substantially reduced in fatal soybean asthma. These data together with the clinical features of the fatal attack suggest a different mechanism(s) from that described for most asthma deaths, probably involving anaphylaxis.

Eur Respir J., 1996, 9, 54-57.
*University of Southampton, University Medicine, Southampton General Hospital, Southampton, UK. ${ }^{* *}$ Institut Municipal d'Investigaciò Mèdica, Barcelona, Spain. +Wellington School of Medicine, Wellington South, New Zealand.

Correspondence: M. Synek

Dept of Paediatrics

York District Hospital

Wigginton Road

York YO3 7HE

UK

Keywords: Anaphylaxis

cellular infiltration

fatal soybean asthma

immunopathology

Received: November 71994

Accepted after revision September 261995
Between 1981 and 1987, 26 asthma outbreaks occurred in Barcelona, Spain, causing 24 deaths. These epidemic asthma attacks had two characteristic features. Firstly, the patients affected were mild asthmatics, well-controlled on inhaled $\beta_{2}$-agonists and, in some cases, on small doses of inhaled corticosteroids. Secondly, severe asthma symptoms developed suddenly and, if death was not the outcome, were quickly relieved after treatment at hospital-based emergency rooms. Using epidemiological methods, it was discovered that the asthma attacks had been caused by inhalation of soybean dust during the unloading of soybean cargoes at a specific harbour silo. As a result, efficient bag filters were fitted to the top of the silo and the asthma outbreaks ceased [1-3].

The pathological basis for these asthma attacks has not previously been explored. Because death was often sudden and unexpected, only seven postmortem specimens of the 24 deaths were obtained. The airway inflammation reflected by cell infiltration is a well recognized feature of asthma. As suggested by SuR et al. [4], the pattern of fatal asthma attack may influence the immunohistochemical findings.

The purpose of this study was to test whether the clinical features of fatal soybean dust-induced asthma were reflected by characteristic immunopathological findings in terms of cellular infiltration when compared with "ordinary" fatal asthma cases.

\section{Methods}

Cases

The following cases were included in the study: 1) seven cases of fatal soybean dust-induced asthma from Barcelona, Spain; and 2) 25 cases of fatal asthma from 
New Zealand as controls. The cases from Barcelona were defined according to the following criteria: 1) they died during an epidemic asthma day as defined previously [2]; and 2) they were either admitted to hospital in at least one epidemic asthma day before the day of death, or they died unexpectedly during an epidemic asthma day showing postmortem findings consistent with asthma.

These subjects were mild asthmatics, mainly treated with $\beta_{2}$-agonists. The interval between the onset of attack and fatal outcome was less than $1 \mathrm{~h}$, thus placing them in the category of sudden-onset asthma [4].

The fatal asthma cases from New Zealand included severe asthmatics who died from asthma in the 1970s and 1980s. Four of them could be described as suddenonset and six as slow-onset asthma deaths [4]. In 15, the time interval between the onset of attack and fatal outcome was unclear. Detailed clinical data of New Zealand fatal asthma cases have been reported previously [5]. It is the purpose of this report to focus on the major findings of soybean asthma in which the New Zealand data serve as a control. Basic information and its comparison with cases from Barcelona is given in table 1 .

T-cell evaluation in the specimens from New Zealand was performed at the later stage of the study and sections were simultaneously taken from the blocks for other studies. As a consequence, the number of specimens containing an amount of tissue sufficient for reliable evaluation was reduced to 10 .

\section{Sample processing}

The specimens from Spain and New Zealand were subjected to identical processing described in detail previously [5]. The lung tissue blocks were taken at postmortem, fixed in formalin and embedded in paraffin. The sections were stained by monoclonal antibodies using standard streptavidin-biotin peroxidase technique. The following cell types were identified: mast cells (AA1: tryptase, University Pharmacology, University of Southampton, UK); "activated" eosinophils (EG2: secreted cationic protein, Pharmacia, Uppsala, Sweden); neutrophils (antielastase, Dako, Glostrup, Denmark); monocytes/macrophages (KP1/CD68: surface marker, Dako, Glostrup, Denmark); CD3+ T-cells (rabbit antibody, Dako, Glostrup, Denmark); and CD8+ T-cells (Dako, High Wycombe, UK).

Table 1. - Clinical and demographic data of the cases

\begin{tabular}{lccccc}
\hline Group & Subj & $\begin{array}{c}\text { Mean age } \\
\text { yrs }\end{array}$ & $\begin{array}{c}\text { Sex } \\
\text { M:F }\end{array}$ & $\begin{array}{c}\text { Steroids } \\
\text { None/ } \\
\text { inhaled/ } \\
\text { oral/ }\end{array}$ & $\begin{array}{c}\text { Smoker } \\
\text { Current/ } \\
\text { ex/ } \\
\text { never }\end{array}$ \\
\hline $\begin{array}{l}\text { Fatal } \\
\text { asthma }\end{array}$ & 7 & 66 & $2: 5$ & $3 / 2 / 0^{*}$ & $3 / 0 / 3^{* *}$ \\
$\begin{array}{l}\text { Soybean } \\
\text { asthma }\end{array}$ & 25 & 40 & $13: 12$ & $3 / 17 / 11^{\dagger}$ & $4 / 6 / 11^{\dagger \dagger}$ \\
\hline
\end{tabular}

*: therapy unknown in two subjects; **: smoking history in one subject; + : therapy unknown in two subjects, and another six had both inhaled and oral steroids; †: smoking history unknown in four subjects. Subj: subjects; M: male; F: female.

\section{Analysis of cellular infiltrate}

The method and calculations have been described previously [5]. Briefly, the cellular infiltrate was quantified for each cell type in the epithelium and submucosa. The epithelium and submucosa were defined according to the method of JAMES et al. [6] and the internal perimeter $(\mathrm{Pi})$ was defined by basement membrane. The airways were divided into two groups, thus enabling larger ( $\mathrm{Pi}>2 \mathrm{~mm}$ ) and smaller ( $\mathrm{Pi}<2 \mathrm{~mm}$ ) airways to be evaluated separately. The selection of $2 \mathrm{~mm} \mathrm{Pi}$ as the cutoff for describing airway size was based on the fact that airways with $\mathrm{Pi}<2 \mathrm{~mm}$ belong to an anatomically welldefined group, the small membranous bronchioli [7]. Specimens from New Zealand contained 51 larger and 51 smaller airways in all, and specimens from Barcelona contained 12 larger and 11 smaller airways in all, thus giving a balanced ratio of both size groups.

Positively stained cells in the epithelium were expressed as the number per $\mathrm{mm}$ of Pi. Cells identified in the submucosa were expressed per $\mathrm{mm}^{2}$ of submucosal area.

\section{Data processing and statistics}

The counts for each cell type were compared between the two groups using the Mann-Whitney U-test. Cell numbers for all airways present in each section were averaged for each subject and summarized by a median. Firstly, all airways taken together were evaluated; and subsequently, larger $(\mathrm{Pi}>2 \mathrm{~mm})$ and smaller $(\mathrm{Pi}<2 \mathrm{~mm})$ airways were studied separately.

\section{Results}

The soybean dust-induced asthma displayed numbers of mast cells, eosinophils, monocytes/macrophages and neutrophils in the epithelium and submucosa similar to fatal asthma cases from New Zealand. This applied to all airways studied together as well as to larger ( $\mathrm{Pi}>2$ $\mathrm{mm}$ ) and smaller ( $\mathrm{Pi}<2 \mathrm{~mm}$ ) airways studied separately. The principal differences between the two groups were in the numbers of T-cells.

In all airways, the numbers of $\mathrm{CD} 3+$ and CD8+ Tcells present in the epithelium and submucosa were significantly lower in soybean dust-induced asthma than in cases from New Zealand. The results are summarized in table 2.

In larger airways the numbers of CD3+ T-cells in the epithelium were similar in the two groups, but the numbers in the submucosa were significantly lower in fatal soybean dust-induced asthma than in fatal cases from New Zealand. The numbers of CD8+ T-cells were significantly reduced in fatal soybean dust-induced asthma both in the epithelium and submucosa (table 2).

In smaller airways, the epithelial numbers of CD3+ and CD8+ T-cells were not significantly different between the two groups. The numbers of CD3+ T-cells in the submucosa were not significantly different either, but CD8+ T-cell counts were significantly reduced in fatal soybean dust-induced asthma (table 2). 
Table 2. - T-cell counts in all airways

\begin{tabular}{llllcc}
\hline Cells & & & FSA & FA & p-value \\
\hline All & & & & & \\
CD3+ & Epithelium & cells $\cdot m^{-1}$ & 0.00 & 0.35 & 0.023 \\
& Submucosal & cells $\cdot m^{-2}$ & 1.4 & 66.0 & 0.003 \\
CD8+ & Epithelium & cells $\cdot m^{-1}$ & 0.09 & 1.19 & 0.009 \\
& Submucosal & cells $\cdot m^{-2}$ & 9.3 & 110.2 & 0.001 \\
Large & $(\mathbf{P i}>\mathbf{2 m m})$ \\
CD3+ & Epithelium & cells $\cdot \mathrm{mm}^{-1}$ & 0.00 & 0.08 & NS \\
& Submucosal & cells $\cdot \mathrm{mm}^{-2}$ & 1.4 & 75.0 & 0.027 \\
CD8+ & Epithelium & cells $\cdot \mathrm{mm}^{-1}$ & 0.08 & 1.36 & 0.008 \\
& Submucosal & cells $\cdot \mathrm{mm}^{-2}$ & 6.2 & 1.02 & 0.022 \\
Small & $(\mathbf{P i}<\mathbf{2 m m})$ & & & & \\
CD3+ & Epithelium & cells $\cdot \mathrm{mm}^{-1}$ & 0.00 & 0.12 & NS \\
& Submucosal & cells $\cdot \mathrm{mm}^{-2}$ & 0.00 & 34.2 & NS \\
CD8+ & Epithelium & cells $\cdot \mathrm{mm}^{-1}$ & 0.00 & 0.26 & NS \\
& Submucosal & cells $\cdot \mathrm{mm}^{-2}$ & 20.0 & 153.1 & 0.016 \\
\hline
\end{tabular}

FSA: fatal soybean asthma; FA: fatal asthma (unrelated to soybean dust exposure). Ns: nonsignificant.

\section{Discussion}

We have observed that fatal soybean dust-induced asthma is associated with reduced numbers of CD3+ and CD8+ T-cells in the epithelium and submucosa of airways when compared with a group of fatal asthma cases. This reduction was more pronounced when all airways together or larger airways only were studied than in smaller airways.

The "baseline" asthma severity in terms of repeated hospital admissions and the need for treatment with corticosteroids was higher in New Zealand fatal cases than in fatal soybean asthma. Despite this and the different pattern of asthma attacks, the numbers of mast cells, eosinophils, monocytes/macrophages and neutrophils in the airways were similar in both groups.

Various factors may influence the immunopathological findings. Treatment with corticosteroids has been shown to reduce mast cell and eosinophil counts [8]. Epitope preservation can vary according to the delay between death and postmortem and the degranulation/disintegration of cells detracts from the accuracy of counting.

The role of T-cells in the pathogenesis of asthma remains controversial. Whereas CD3+ T-cells represent a broader definition of T-lymphocytes, the functions of CD8+ T-cells are relatively well-defined. They fall into two distinct subgroups: antigen-specific supressor cells inhibiting immunoglobulin E (IgE) production by B-cells; and natural killers, cytotoxic cells killing targets expressing foreign major histocompatibility complex (MHC) class I associated antigen $[9,10]$. It is not clear whether they are acting in a proinflammatory or counterinflammatory role. High serum levels of specific IgE antibodies directed against soybean antigens were found in patients affected by asthma outbreaks in Barcelona [11]. This is in keeping with low numbers of downregulating CD8+ T-cells. The numbers of CD8+ T-cells in fatal soybean asthma exceeded those of CD3+ T-cells, probably because some CD8+ natural killers did not express the CD3 receptor. Patients with acute nonfatal exacerbations of asthma show raised expression of activation markers in peripheral blood T-cells $[12,13]$. It is, therefore, unexpected to find decreased numbers both of CD8+ and CD3+ T-cells in fatal asthma. The simplest explanation is that fatal attack in soybean asthma developed so suddenly that death occurred before many lymphocytes could infiltrate the airways. It has to be considered that soybean dust may have contained endotoxin(s) causing a bronchoconstriction via direct effect on bronchial smooth muscle [14]. This explanation is supported by a rapid relief of symptoms after treatment, unless death was the outcome. However, the anaphylactic-like reaction would have followed a similar pattern. Another possible factor is cigarette smoking which increases the level of nonspecific IgE antibodies. Smokers have decreased numbers of T-cells and B-cells in the lungs with a normal T:B ratio [15]. As not all fatal soybean dust-induced asthma cases were smokers, this would not explain the reduction observed across the whole group. Severe asthma has been associated with a deficiency of T-cell function [16], which particularly affects CD8+ Tcells. Thus, CD8+ infiltration may represent a protective mechanism against airways inflammation, although precisely how this operates remains unclear.

We have been unable to show any significant difference in the numbers of mast cells, eosinophils and neutrophils in relation to "baseline" asthma severity or to the pattern of fatal attack. This is probably due to corticosteroid therapy, which supressed the inflammation and reduced differences between the groups. Nor was it possible to assess the state of mast cell and eosinophil degranulation in paraffin-embedded tissue stained immunohistochemically.

We conclude that fatal soybean asthma has characteristic immunopathological findings different from those of fatal asthma unrelated to the exposure to soybean dust. The high levels of specific IgE in these cases [11] provide ideal circumstances for an anaphylactic-like response as the most likely, although not the only possible, explanation.

\section{References}

1. Antó JM, Sunyer J. Epidemiologic studies of asthma epidemics in Barcelona. Chest 1990; 98: 185S-190S.

2. Antó JM, Sunyer J, Rodríguez-Roisín R, Suárez-Cervera M, Vázquez L, and the Toxicoepidemiological Committee. Community outbreaks of asthma associated with inhalation of soybean dust. N Engl J Med 1989; 320: 1097-1102.

3. Antó JM, Sunyer J, Reed CE, et al. Preventing asthma epidemics due to soybeans by dust-control measures. $N$ J Engl Med 1993; 329: 1760-1763.

4. Sur S, Crotty TB, Kephart GM, et al. Sudden-onset fatal asthma: a distinct entity with few eosinophils and relatively more neutrophils in the airway submucosa? Am Rev Respir Dis 1993; 148: 713-719.

5. Synek M, Beasley R, Frew AJ, et al. Cellular infiltration of the airways in asthma of varying severity. Am J Respir Crit Care Med 1995; (in press).

6. James AL, Hogg JC, Dunn LA, Parre PD. The use of the internal perimeter to compare airway size and to calculate smooth muscle shortening. Am Rev Respir Dis 1988, 138: 136-139. 
7. Carroll N, Elliot J, Morton A, James A. The structure of large and small airways in nonfatal and fatal asthma. Am Rev Respir Dis 1993; 147: 405-410

8. Djukanovic R, Wilson JW, Britten KM, et al. Effect of an inhaled corticosteroid on airway inflammation and symptoms of asthma. Am Rev Respir Dis 1992; 145: 669-674.

9. Curtis JL, Byrd PK, Warnock ML, Beck JM, Kaltreider HB. Pulmonary lymphocyte recruitment: depletion of CD8+ T-cells does not impair the pulmonary immune response to intratracheal antigen. Am J Cell Mol Biol 9; 1993: 90-98.

10. Monaco JJ. A molecular model of MHC class I restricted antigen processing. Immunol Today 1992; 13: 173-179.

11. Sunyer J, Anto JM, Rodrigo MJ, Morrell F. Casecontrol study of serum immunoglobulin E antibodies reactive with soybean in epidemic asthma. Lancet i; 1989: 179-182.

12. Robinson DS, Bentley AM, Hartnell A, Kay AB, Durham
SR. Activated memory T-helper cells in bronchoalveolar lavage fluid from patients with atopic asthma: relation to asthma symptoms, lung function and bronchial responsiveness. Thorax 1993; 48: 26-32.

13. Corrigan CJ, Kay AB. CD4 T-lymphocyte activation in acute severe asthma. Am Rev Respir Dis 1990; 141: 970-977.

14. Michel O, Ginanni R, Le Bon B, Content J, Duchateau J, Sergysels R. Inflammatory response to acute inhalation of endotoxin in asthmatic patients. Am Rev Respir Dis 1992; 146: 352-357

15. Daniele RP, Dauber JH, Altose MD, Rowlands DT, Gorenberg DJ. Lymphocyte studies in asymptomatic cigarette smokers: a comparison between lung and peripheral blood. Am Rev Respir Dis 1977; 116: 997-1005.

16. Beer DJ, Osband ME, McCaffrey RP, Sotér NA, Rocklin RE. Abnormal histamine-induced suppressor cell function in atopic subjects. N Engl J Med 1982; 306: 454-458. 